\title{
Early colonization on Artificial Seagrass Units and on Posidonia oceanica (L.) Delile leaves
}

\author{
Dorothée C. Pête ${ }^{1, *}$, Gilles Lepoint ${ }^{1}$, Jean-Marie Bouquegneau ${ }^{1} \&$ Sylvie Gobert $^{1}$ \\ ${ }^{1}$ Laboratory of Oceanology, MARE Center, University of Liège, Institut de Chimie, B6C, Allée du 6 août 13, 4000 Liège, \\ Belgium. \\ * Corresponding author: Dorothee.Pete@ulg.ac.be
}

\begin{abstract}
Many epiphytes grow on Posidonia oceanica (L.) Delile leaves but early stages of that colonization are not well known. To study this early colonization without destroying the plant, Artificial Seagrass Units (ASUs) were utilised. The first nine days of colonization by macroscopic eukaryotic organisms on natural $P$. oceanica leaves and on ASUs were studied. The capability of those ASUs to mimic $P$. oceanica in the long term was also evaluated. Indeed, early colonists of a substrate can influence the settling of later ones by "priority effects". Thus if the pioneer community is the same on both substrates, they will more likely be the same after a longer exposure time. On both substrates, colonization began by the settling of crustose-calcareous algae and foraminiferans. The number of organisms increased more quickly on ASUs than on natural leaves but Shannon-Wiener diversity index was higher for $P$. oceanica leaves. The low colonization rate on natural leaves may have been due to different microclimatic conditions on the two substrates and to a less developed biofilm than on ASUs. The high diversity observed on natural leaves was mainly related to the presence of bryozoan ancestrulae, which were absent on ASUs. Different microhabitats on each substrate (different algae morphotypes) can explain this difference. Thus, at such an early colonization stage, pioneer communities were different on the two substrates, suggesting that later communities would be different too. However, ASUs could be used in environmental perturbation studies instead of natural leaves, thanks to their high colonization rate.
\end{abstract}

KEY WORDS: seagrass, artificial substrata, epiphytes, colonization, substrate preferences.

\section{INTRODUCTION}

In the Mediterranean coastal zone, the seagrass Posidonia oceanica (L.) Delile forms dense meadows. The leaves of this seagrass are long (up to $130 \mathrm{~cm}$ ) and have the longest life span among seagrasses (up to 56 weeks) (THELIN \& BOUDOURESQUE, 1983; GOBERT et al., 2005). Thus, they can support an important epiphytic community that is composed of many organisms such as bacteria, diatoms, dinoflagellates, red and brown macroalgae, protists, sponges, bryozoans, hydrozoans and annelids (KERNEIS, 1960; MAZZELla et al., 1981; CASOla et al., 1987; MAZZELLA et al., 1989; JACQUEMART \& Demoulin, 2006; MABrouk et al., 2011; LEPOINT et al., 2014). In total they can represent up to $40 \%$ of the leaf biomass (GOBERT et al., 1995) and their density increases with leaf age (NovaK, 1984). P. oceanica leaves grow from a basal meristem. Youngest parts of the plant are situated at the basis of the leaves and in the centre of the shoots. They grow from the centre to the external part of the shoot, tightly packed with older leaves. Epiphytes are thus more abundant on the outer leaves of the shoots than on the inner ones and on the leaf tips than on the bases (VAN DER BEN, 1971; CASOla et al., 1987). On the young parts of the plant, the epiphyte cover is mainly constituted of bacteria and diatoms that form a biofilm (NOVAK, 1984). Biofilms are important in marine environments because they condition the settling of organisms on immerged substrates (CRISP \& RYLAND, 1960; KeOUgh \& Raimondi, 1995; De Troch et al., 2005). On older parts of $P$. oceanica, macroepiphytes become dominant, even if they can be secondarily colonized by bacteria or other micro-organisms (NovAK, 1984). 
Epiphytes also contribute to the food webs associated with the $P$. oceanica ecosystems (MAZZELLA et al., 1992; LEPOINT et al., 2000; MichEL, 2011). Their biomass, biodiversity, abundance and/or coverage are used in pollution studies because they react more quickly to environmental perturbations than does the plant itself, thanks to their rapid turnover and their high nutrient uptake rates (MORRI, 1991; PERGENTMARTINI et al., 2005; LEPOINT et al., 2007; GOBERT et al., 2009).

The daily evolution of early epiphyte settling on $P$. oceanica leaves is not known, although it can influence subsequent epiphytic assemblages. Indeed, according to the theory of CONNELL \& SLATYER (1977), the first colonists of a substrate influence later colonists by facilitating or inhibiting their settling and persistence. First colonizers are able to influence the recruitment of other organisms by creating some specific conditions in the environment or by limiting the possible interspecific interactions with newly-arriving species (BOLOGNA \& HECK, 1999; IRVING et al., 2007). These phenomena are called "priority effects" (BELYEA \& LANCASTER, 1999). The identification of early colonizers is thus essential to understanding the dynamics of the epiphytic community living on $P$. oceanica leaves.

Artificial Seagrass Units (ASUs) are interesting in the study of the epiphyte colonization of seagrass leaves because they can be set up anywhere, regardless of conditions (BARBER et al., 1979; LEE et al., 2001) and they allow the control of parameters such as leaf number, shoot density, leaf length and width, as well as the surface available for colonization (BOLOGNA \& HECK, 1999; TRAUTMAN \& BOROWITZKA, 1999). Moreover, they represent a non-destructive method, which is particularly important when working with protected species such as $P$. oceanica (DONNARUMMA et al., 2014).

The aims of this study were to identify the first sessile macroscopic eukaryotic organisms settling on the basal parts of $P$. oceanica leaves and ASUs, day by day during nine days, and then to determine if those ASUs are able to mimic natural leaves, in order to use them instead of the natural plant to study the colonization of $P$. oceanica by epiphytes or to detect environmental perturbations. Indeed, if the pioneer community composition and abundances are the same on ASUs as on $P$. oceanica, subsequent colonists will more likely be the same on both substrates too (CONNELL \& SLATYER, 1977; IRVING et al., 2007; MAGGI et al., 2011).

\section{MATERIALS AND METHODS}

This study was realised from March $5^{\text {th }}$ to March $14^{\text {th }} 2005$, at a depth of $10 \mathrm{~m}$, in front

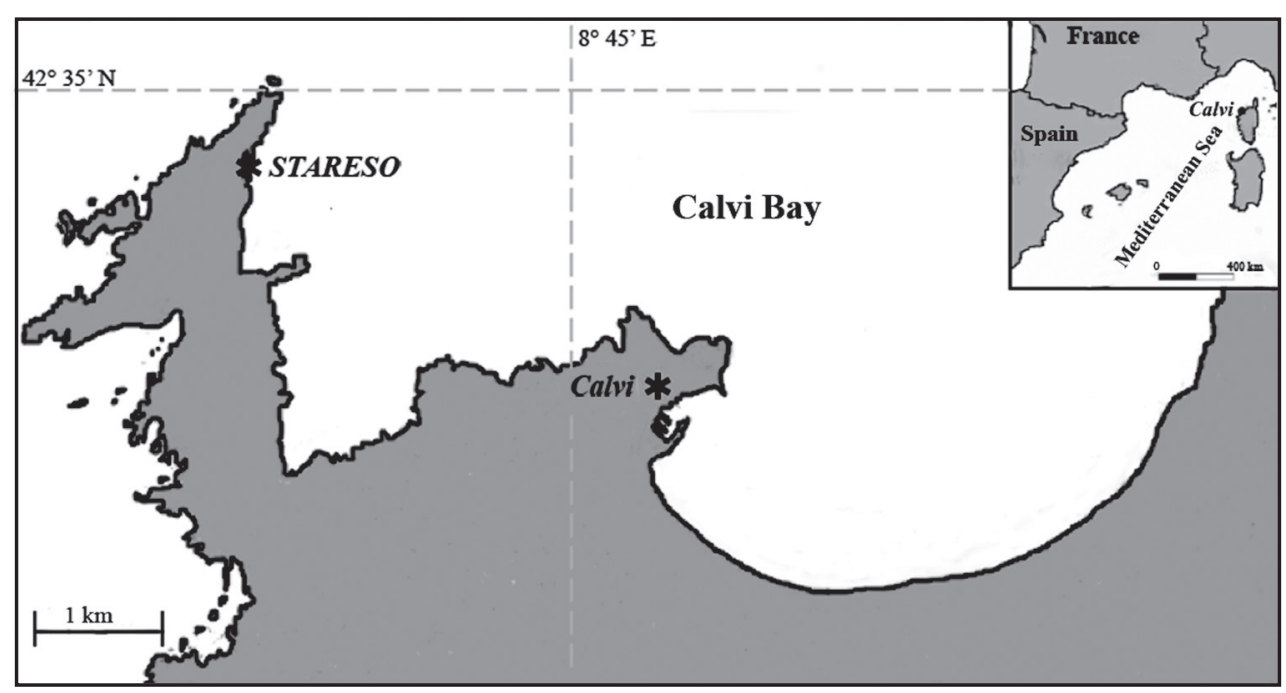

Fig. 1 - Sampling site. The sampling site is situated in front of the research station STARESO, Corsica, France, in the $P$. oceanica meadow, at a depth of $10 \mathrm{~m}$. 
of the STARESO research station (Fig.1, Calvi Bay, Corsica, France, $42^{\circ} 35^{\prime} \mathrm{N}, 8^{\circ} 43^{\prime} \mathrm{E}$ ). This site is characterized by a continuous $P$. oceanica meadow where the shoot density varies from 400 to 700 shoots. $\mathrm{m}^{-2}$ at a depth of $10 \mathrm{~m}$ (SOULLARD et al., 1994).

Every Artificial Seagrass Unit (ASU, Fig. 2) was made of a black PVC ribbon (width $=1 \mathrm{~cm}$, length $=50 \mathrm{~cm}$, thickness $=0.5 \mathrm{~mm}$ ) with a float (Eppendorf tube) at the free end to maintain those ASUs in the same position as natural leaves. They were fixed on a ballasted PVC tube and the whole structure was put inside the meadow. At the same time (day 0 of the experiment), ten $P$. oceanica shoots were marked with the punching hole method (ZIEMAN \& WETZEL, 1980) to assure that both substrates had been exposed to the same pool of colonists during the same period. Indeed, as $P$. oceanica leaves grow from a meristem situated in the centre of the shoot, it was assumed that the zone of the youngest marked leaf (GIRAUD, 1979) situated under the hole experienced the same exposure time as the ASUs. As the youngest parts of $P$. oceanica leaves are wrapped in the sheaths of old leaves, it was impossible to define more precisely this newly exposed zone.
Every day during nine days (after day 0), one ASU and one marked natural shoot were picked up by scuba diving. The youngest punched leaf of each natural shoot was selected (GIRAUD, 1979) and the inner and outer surfaces of the freshly exposed zone were observed ( 0 to $4.2 \mathrm{~cm}^{2}$ ) with a magnification of fifty times, to determine the density of sessile macroscopic eukaryotic organisms. To compare with natural leaves, only the basal parts $(0-5 \mathrm{~cm})$ of ASUs were observed.

Organisms were determined at phylum level. To compare the contribution of each phylum on both substrates, relative abundances (percentage of the total number of organisms in each sample) were calculated. Sample diversity was also estimated using Shannon-Wiener diversity index, calculated with a DIVERSE analysis in PRIMER 6 (CLARKE \& WARWICK, 2001).

A preliminary study was carried out on the samples collected after four days of exposure using scanning electron microscopy (SEM), in order to illustrate some epiphytes and the development of the biofilm on every substrate. A portion of $0.5 \mathrm{~cm}^{2}$ was selected at the bases of natural and artificial leaves and fixed in $4 \%$ seawater glutaraldehyde for a few days, at $4^{\circ} \mathrm{C}$.

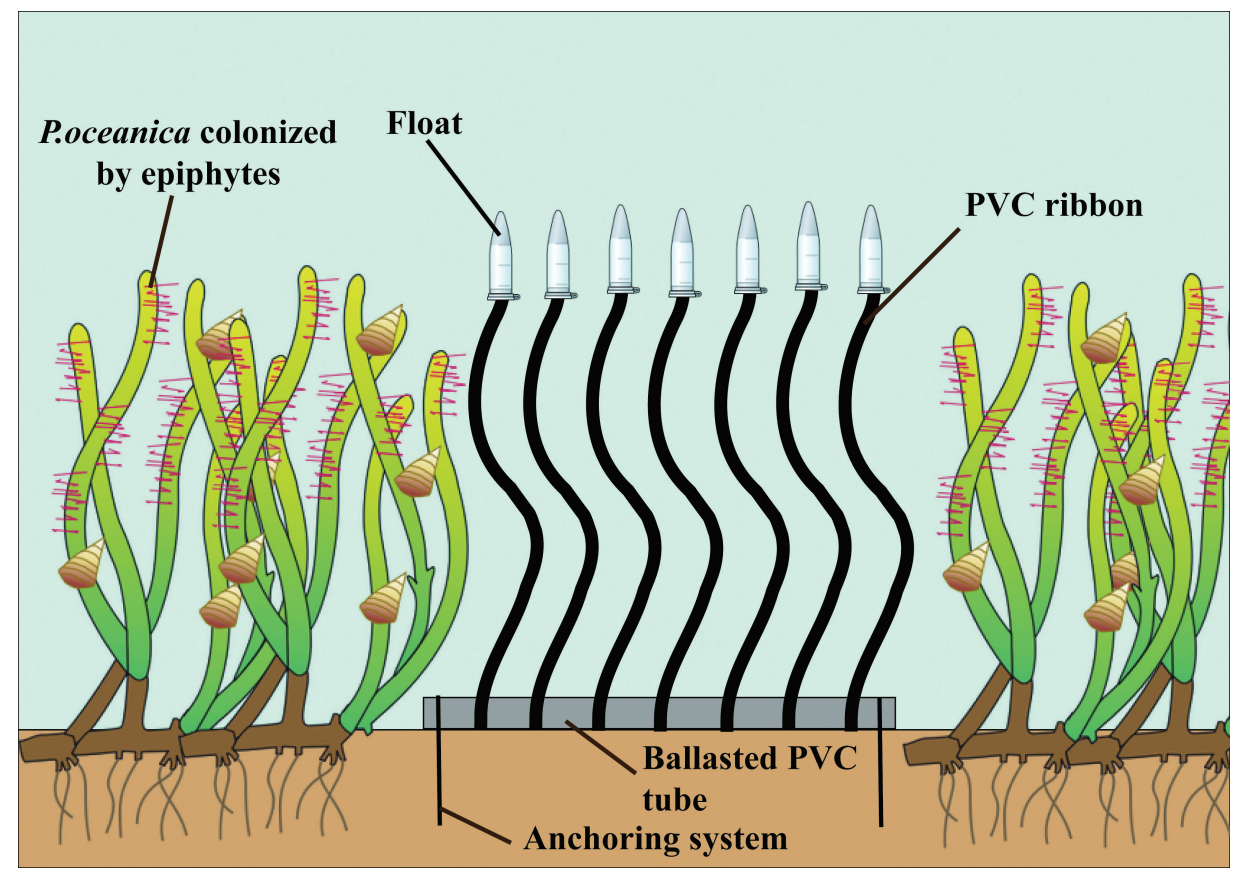

Fig. 2 - Experimental device for the Artificial Seagrass Units (symbols used with the courtesy of the Integration and Application Network, University of Maryland Center for Environmental Science (ian.umces.edu/symbols/)). 
TABLE 1

Shannon-Wiener diversity index (H') calculated for each sampling day from phylum abundances on ASUs and P. oceanica natural leaves (N.D.: no data).

\begin{tabular}{|c|c|c|c|c|c|c|c|c|c|}
\hline $\begin{array}{c}\text { Duration of the } \\
\text { colonization (days) }\end{array}$ & 1 & 2 & 3 & 4 & 5 & 6 & 7 & 8 & 9 \\
\hline ASUs & $/$ & 0.26 & 0.17 & 0.29 & 0.12 & 0.56 & 0.60 & N.D. & 0.68 \\
Natural leaves & $/$ & 0.00 & 0.00 & 0.64 & 0.64 & N.D. & 0.67 & N.D. & 0.92 \\
\hline
\end{tabular}

They were then rinsed in seawater filtered on a $0.22 \mu \mathrm{m}$ filter, post-fixed in $1 \%$ seawater $\mathrm{OsO}_{4}$, rinsed again in seawater and critical point dried. They were mounted on aluminium stubs and coated with a thin layer of gold-palladium for the SEM observation. It is worth mentioning that the use of distilled water in the preparation of SEM samples of both studied substrates seemed to wash out most of the organisms. It should therefore be avoided.

\section{RESULTS}

On both substrates (Fig. 3), the first sessile macroscopic eukaryotic organisms settled after 2 days. The number of colonists increased with time but this increase was more important for

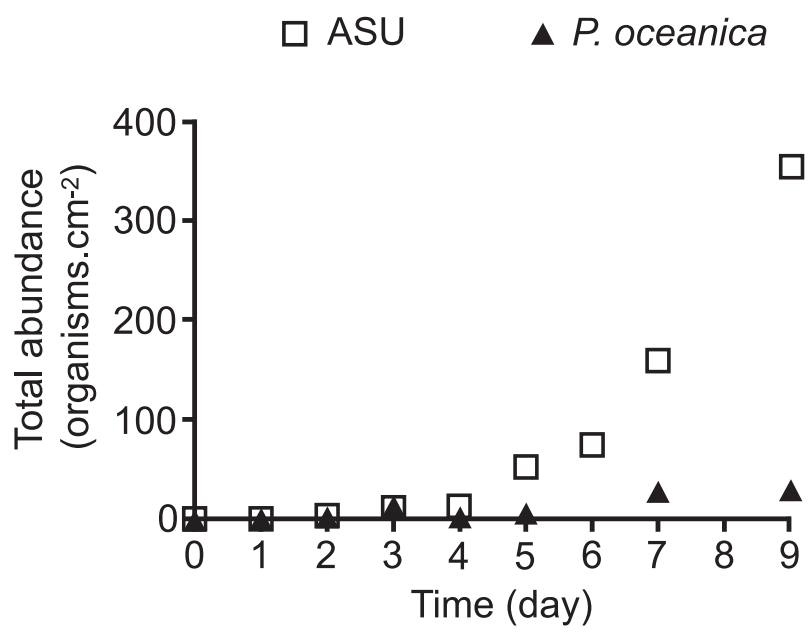

Fig. 3 - Evolution of epiphyte density (organisms. $\mathrm{cm}^{-2}$ ) over time on the bases of natural leaves (triangles) and ASUs (squares).
ASUs. Indeed, the colonist density was only 29 organisms per square centimetre $\left(\right.$ org. $\left.\mathrm{cm}^{-2}\right)$ on $P$. oceanica leaves after nine days while it reached 355 org. $\mathrm{cm}^{-2}$ on ASUs. Except for the third sampling day, the total abundance was always 3 to 12 times higher on ASUs than on natural leaves.

Shannon-Wiener diversity index (H', Table 1) increased throughout the experiment for natural leaves while this increase was only clear after 5 days of exposure for ASUs. From the fourth sampling day, H' was always higher for the basal parts of natural leaves than for those of ASUs.

After only 4 days (Table 1, Fig 4), sessile communities colonizing natural leaves were more diverse than those settling on ASUs. This fact is also clear when looking at phyla relative abundances. On both substrates, the observed phyla were macroalgae, ciliates, foraminiferans and bryozoans, but their relative abundances (Fig. 4) were different.

On natural leaves (Fig. 4A), the community showed a dominance of algae (20\% after 5 days to $100 \%$ after 3 days) and foraminiferans (15\% after 7 days to $100 \%$ after 2 days). After 7 days, bryozoans became important too (5-6\%).

On ASUs, the dominant phylum, before 6 days of exposure, was algae (Fig. 4B, between $85 \%$ after 4 days and $97 \%$ after 5 days). From the 6 th sampling day to the end of the experiment, there was a switch between algae (39\% after 9 days) and foraminiferans (61\% after 9 days). 
Whenever other phyla were observed, they represented less than $2 \%$ of the total abundance on both substrates.

\section{DISCUSSION}

Epiphyte biomass on $P$. oceanica leaves increases with leaf age and follows a sigmoid distribution (CEBRIÁN et al., 1999). The stabilization of the curve is reached when there is a balance between epiphyte growth and losses, due, for example, to grazing pressure (VAN MONTFRANS et al., 1984; BORUM, 1987; AlCOVERRO et al., 1997). In this study, the obtained curves (Fig. 3) are in the exponential part of the sigmoid curve because of the shortness of the experiment (BORUM 1987). Indeed, the exposure time here is 9 days while CEBRIÁN et al. (1999) have shown that epiphyte biomass on $P$. oceanica leaves reaches the upper part of the sigmoid distribution after 270 days.

The curve for ASUs showed a highly increasing density of organisms towards the end of the experiment, suggesting that colonization was in an active phase. This rapid increase in colonist density may be due to a "snowball effect". Indeed, it was proven that colonization modifies the leaf surface and favours the recruitment of new colonizers (NOVAK, 1984; BOLOGNA \& HeCK, 1999; IRving et al., 2007). So, in the early phase of colonization, if more organisms settle on a substrate, the colonization by new organisms is favoured.
In comparison with ASUs, the increase in epiphyte density on P. oceanica leaves was low, although the Shannon-Wiener diversity index was higher. These observations are in accordance with those of other authors comparing ASUs with aquatic macrophytes (CATTANEO \& KALFF, 1978; NOVAK, 1984; EDGAR, 1991). The difference between both types of substrates can be explained by the existence of a longer lag phase before active epiphyte colonization for $P$. oceanica than for ASUs. This lag phase is the period needed by a substrate to be ready to be colonized. It depends on bacterial communities living on the leaves and on the maturity of the biofilm, which grows importantly during the early stages of colonization (KEVERN et al., 1966; NovaK, 1984; KeOUGH \& RAIMONDI, 1995, 1996; DAHMS et al., 2004). SEM observations of samples of each substrate, after 4 days of exposure, confirmed that a more complex biofilm was present on ASUs than on natural leaves (Fig. 5A-B).

Another reason for a lower colonization rate of natural leaves in comparison with ASUs is the production of secondary metabolites, such as phenolic compounds, by the plant. Those chemicals can influence the biofilm and the epiphytic cover that settle on seagrasses by acting as an antifouling agent or by selecting species adapted to resist those compounds (HARRISON \& Chan, 1980; NovaK, 1984; JENSEN et al., 1998). For P. oceanica, the production of phenolic compounds presents a seasonal pattern, depends on environmental stress (competition, sewage...) and is higher in intermediate leaves than in adult
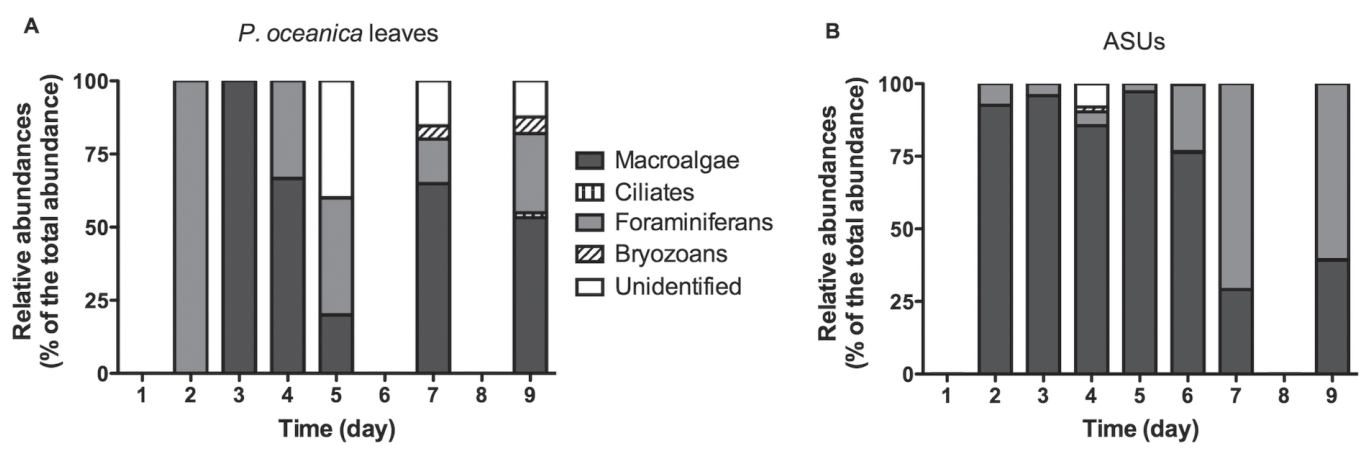

Fig. 4 - Evolution of relative abundances of the observed phyla ( $\%$ of the total abundance) over time for natural leaves (A) and ASUs (B). Unidentified: phyla unidentified at the used magnification level. 
ones (CUNY et al., 1995; Agostini et al., 1998; DUMAY et al., 2004). As this study focused on the bases of intermediate $P$. oceanica leaves, the high production of phenolic compounds in those leaves could have influenced the epiphytic cover, either directly or by modifying the biofilm composition.

The difference in microclimatic conditions on the surface of the two substrates could be responsible for the observed differences too. Natural leaves are slightly curved, so the water circulation and the light conditions on their surfaces are probably different to those existing on the completely flat ASUs. The dominant bryozoan on $P$. oceanica leaves, an obligate epiphyte of this plant, Electra posidoniae, is almost entirely restricted to the plant internal curved face (MATRICARDI et al., 1991). So, the scarcity of bryozoans on ASUs and particularly of $E$. posidoniae, also observed by GAMBI et al. (2011) and DonNARUMMA et al. (2014), is probably due to the flatness of ASUs as well as to the absence of the chemicals cited above.

Different microclimatic conditions can also be created on a substrate by the existence of different microhabitat structures that can influence the colonization by micro- or macroorganisms (NOVAK, 1984; GARTNER et al., 2013). According to CASOLA et al. (1987), after the biofilm development, the epiphytic community succession on $P$. oceanica leaves is characterized by, at first crustose-calcareous
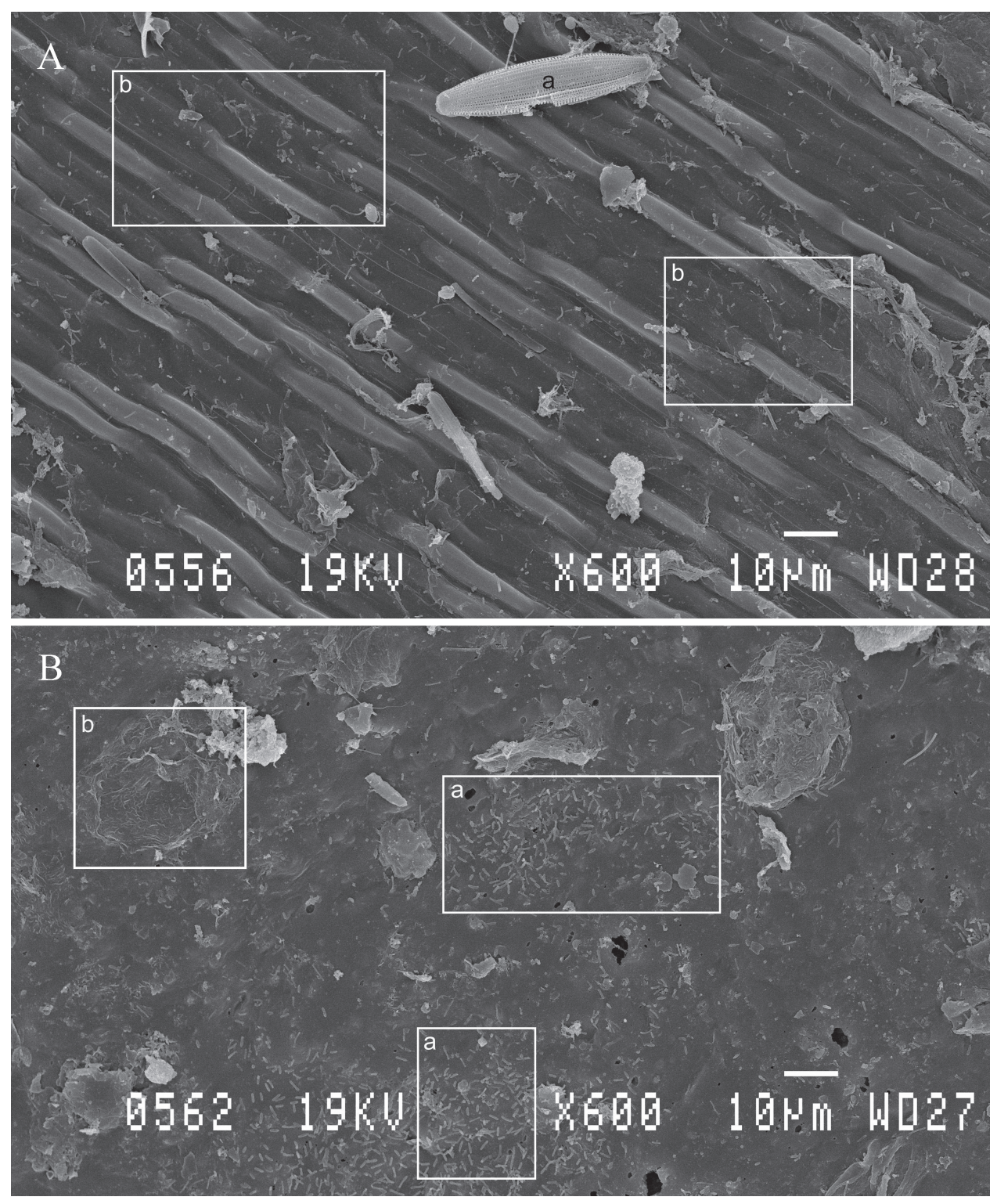

Fig. 5 - SEM pictures (magnification: 600x) of the basal portions of the $P$. oceanica leaf (A) and the ASU (B), showing the difference in microhabitat structure between the two substrates after 4 days of exposure. A. a = diatom, $\mathrm{b}=$ bacterial biofilm in formation. $\mathbf{B} \cdot \mathbf{a}=$ developed bacterial biofilm, $\mathrm{b}=$ biofilm agglutinated by mucus. 
forms (foraminiferans, bryozoans, crustosecalcareous algae), then crustose-noncalcareous forms and finally erect forms. So the community goes from a simple habitat structure (i. e. monolayered biofilm) to a more complex one (i. e. multi-layered structure). Here, the morphology of the algal community was different between the two substrates (Fig. 6). On natural leaves, the classical succession was observed. Crustosenoncalcareous algae became important after 7 days of exposure and some filamentous and erect algae were observed too. On ASUs, crustosecalcareous algae were dominant throughout the exposure period. Thus, as the microhabitat structures and the microclimatic conditions were different on both substrates, the observed communities were different too.

The dominance of crustose-calcareous algae and the scarcity of sessile fauna on artificial Posidonia leaves have also been observed by Michel (2011) and DonNARUMMA et al. (2014), after respectively 76 days and three months of in situ exposure. This suggests that the community structure that is observed here on ASUs is already representative of the later communities. That also underlines the role of microhabitat structure and microclimatic conditions in the establishment of colonists on immersed substrates.

Leaf movements can also influence algal epiphyte biomass (LAVERY et al., 2007). Here, every ASU was formed of a single PVC blade ending with a float. Thus, each ASU probably moved more in the water column than would a natural leaf, especially an intermediate one, which is tightly packed with the other leaves of the seagrass shoot. However, the high density of epiphytes observed on ASUs is in contradiction with results of LAVERY et al. (2007), suggesting that movement was not a limiting factor in our experimental design.

However, the experimental protocol can explain the low colonization rate observed on natural leaves in comparison with ASUs. The very young parts of $P$. oceanica studied here were situated in the centre of the tuft formed by the leaves. In that zone, leaves are tightly arranged side by side so the leaf surface is less accessible for epiphyte propagules or larvae than on ASUs that are not organised in tufts. This low epiphytic cover of the youngest and basal parts of $P$. oceanica shoots has already been observed by CASOLA et al. (1987). It explains only the difference in colonization rate between the two substrates but not the difference in community structures. Indeed, the classical succession on $P$. oceanica leaves was identified on natural leaves after only nine days of exposure while the community structure on ASUs was different (see above).

\section{CONCLUSIONS}

At the end of this study, we can hypothesize that the community present on ASUs after a few months inside the meadow would be different to the one on natural leaves, because the first colonization stages are not the same. Despite the absence of replication and the shortness of this study (nine days of exposure), first steps of
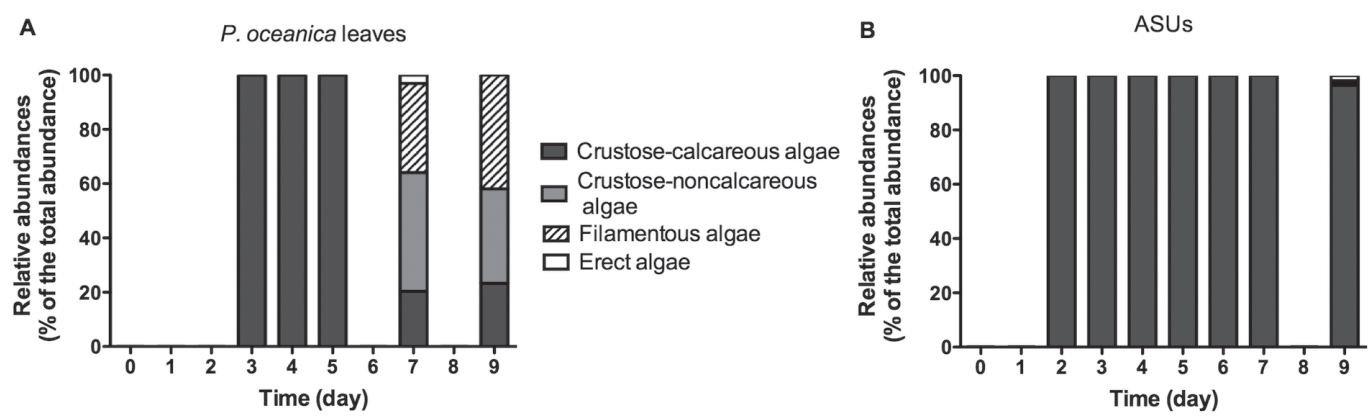

Fig. 6 - Evolution of relative abundances (\% of the total abundance of algae) of the different morphological groups of algae observed on the bases of natural leaves (A) and ASUs (B) over time. 
the classical epiphyte succession on $P$. oceanica leaves (CASOLA et al., 1987) were observed, while the community on ASUs was different. Moreover, dominant (crustose calcareous algae) and absent (bryozoans) groups observed on ASUs in this study were the same as those observed by other authors after a longer exposure time: MiCHEL (2011), 76 days, same ASUs as here; DonNARUMMA et al. (2014), 3 months, different ASUs), suggesting that our results and conclusions are reliable. However, the same study should be performed with more replicates in order to strengthen these conclusions. It would also be interesting to follow the settling of colonists on a longer time scale and to use SEM to study quantitatively the composition and evolution of the biofilm.

ASUs could, however, be useful for the study of environmental perturbations without the use of $P$. oceanica, thanks to the rapidity of their colonization. In that case, further experiments should first characterize the communities present on ASUs in pristine and perturbed locations.

\section{ACKNOWLEDGEMENTS}

We thank the staff of STARESO for receiving us in their installations and for their valuable assistance. We are really grateful to Renzo Biondo and Nicole Decloux for their wonderful technical support. We would like to thank Loïc $\mathrm{N}$. Michel and the reviewers of this paper for their valuable comments. Financial support was provided by the "Fondation de Recherches Sous-marines et Océanographiques" (University of Liege) and the "Fond de la Recherche Scientifique-FNRS" (FRFC contract: 2.4569.03, Research Fellow grant). This paper is the MARE publication number 287.

\section{REFERENCES}

Agostini S, Desjobert JM \& Pergent G (1998). Distribution of phenolic compounds in the seagrass Posidonia oceanica. Phytochemistry, 48:611-617.
Alcoverro T, DuArte CM \& Romero J (1997). The influence of herbivores on Posidonia oceanica epiphytes. Aquatic Botany, 56:93-104.

BARBER WE, GREENWOOD JG \& CRocos P (1979). Artificial seagrass - A new technique for sampling the community. Hydrobiologia, 65:135-140.

BELYEA LR \& LANCASTER J (1999). Assembly rules within a contingent ecology. Oikos, 86:402-416.

Bologna PAX \& HeCK KH (1999). Macrofaunal asociations with seagrass epiphytes: Relative importance of trophic and structural characteristics. Journal of Experimental Marine Biology and Ecology, 242:21-39.

BORUM J (1987). Dynamics of epiphyton on eelgrass (Zostera marina L.) leaves: Relative roles of algal growth, herbivory, and substratum turnover. Limnology \& Oceanography, 32:986-992.

Casola E, Scardi M, Mazzella L \& Fresi E (1987). Structure of the epiphytic community of Posidonia oceanica leaves in a shallow meadow. Marine Ecology, 8:285-296.

CATtaneo A \& KalfF J (1978). Seasonal changes in the epiphyte community of natural and artificial macrophytes in Lake Memphremagog (Que. \& VT.). Hydrobiologia, 60:135-144.

Cebrián J, Enríquez S, Fortes M, Agawin N, VermaAt JE \& DuARTE CM (1999). Epiphyte accrual on Posidonia oceanica (L.) Delile leaves: implication for light absorption. Botanica Marina, 42:123-128.

CONNELl JH \& Slatyer RO (1977). Mechanisms of Succession in Natural Communities and Their Role in Community Stability and Organization. American Naturalist, 111:1119-1144.

CRISP DJ \& RYLAND JS (1960). Influence of filming and of surface texture on the settlement of marine organisms. Nature, 185:119.

Cuny P, Serve L, Jupin H \& Boudouresque CF (1995). Water soluble phenolic compounds of the marine phanerogam Posidonia oceanica in a Mediterranean area colonised by the introduced chlorophyte Caulerpa taxifolia. Aquatic Botany, 52:237-242.

DAHMS HU, DOBRETSOV S \& QIAN PY (2004). The effect of bacterial and diatoms biofilms on the settlement of the bryozoan Bugula neritina. Journal of Experimental Marine Biology and Ecology, 313:191-209.

De Troch M, Vandepitte L, Raes M, SuàrezMORALES E \& VINCX M (2005). A field 
colonization experiment with meiofauna and seagrass mimics: effect of time, distance and leaf surface area. Marine Biology, 148:73-86.

DONNARUMMA L, LOMBARDI C, COCITO S \& GAMBI MC (2014). Settlement pattern of Posidonia oceanica epibionts along a gradient of ocean acidification: an approach with mimics. Mediterranean Marine Science, 15:498-509.

Dumay O, Costa J, Desjobert JM \& Pergent G (2004). Variations in the concentration of phenolic compounds in the seagrass Posidonia oceanica under conditions of competition. Phytochemistry, 65:3211-3220.

EDGAR GJ (1991). Artificial algae as habitats for mobile epifauna: factors affecting colonization in a Japanese Sargassum bed. Hydrobiologia, 226:111-118.

GAmbi MC, Donnarumma L, Lombardi C \& Cocito S (2011). Posidonia oceanica mimics as an experimental tool to study colonization of seagrass epiphytes. An example along a gradient of water acidification. Biologia Marina Mediterranea, 18:252-253.

GARTNER A, TUYA F, LAVERY PS \& MCMAHON K (2013). Habitat preferences of macroinvertebrate fauna among seagrasses with varying structural forms. Journal of Experimental Marine Biology and Ecology, 439:143-151.

GiRAUD G (1979). Sur une méthode de mesure et de comptage des structures foliaires de Posidonia oceanica (Linnaeus) Delile. Bulletin Muséum Histoire Naturelle Marseille, 39:33-39.

Gobert S, Belkhiria S, Dauby P, Havelange S, Soullard M \& BouQuegneau JM (1995). Variations temporelles de la phénologie et de la composition biochimique de la phanérogame marine Posidonia oceanica en baie de Calvi. Bulletin de la Société Royale des Sciences de Liège, 64:263-284.

Gobert S, SARTORETto S, Rico-RAimondino V, ANDral B, Chery A, LeJeune P \& BOISSERY $P$ (2009). Assessment of the ecological status of Mediterranean French coastal waters as required by the Water Framework Directive using the Posidonia oceanica Rapid Easy Index: PREI. Marine Pollution Bulletin, 58:1727-1733.

Gobert S, Cambridge ML, Velimirov B, Pergent G, Lepoint G, Bouquegneau JM, Dauby P, Pergent-Martini C \& Walker DI (2005). Biology of Posidonia. In: LARKUM AWD, ORTH J
\& DUARTE CM (eds), Seagrass Biology, Springer, The Netherlands:387-408.

HARRISON PG \& CHAN AT (1980). Inhibition of the growth of micro-algae and bacteria by extracts of eelgrass (Zostera marina) leaves. Marine Biology, 61:21-26.

IRVING AD, TANNER JE \& MCDONALD BK (2007). Priority effects on faunal assemblages within artificial seagrass. Journal of Experimental Marine Biology and Ecology, 340:40-49.

JACQUEMART J \& DEMOULIN V (2006). Inventaire des macroalgues épiphytes des feuilles de Posidonia oceanica (L.) Delile dans la Baie de la Revellata (Calvi, Corse). Lejeunia, 181:1-71.

Jensen PR, Jenkins KM, Porter D \& Fenical W (1998). Evidence that a New Antibiotic Flavone Glycoside Chemically Defends the Sea Grass Thalassia testudinum against Zoosporic Fungi. Applied and Environmental Microbiology, 64:1490-1496.

Keough MJ \& RAimondi PT (1995). Responses of settling invertebrate larvae to bioorganic films: Effects of different types of films. Journal of Experimental Marine Biology and Ecology, 185:235-253.

KeOUGH MJ \& RAIMONDI PT (1996). Responses of settling invertebrate larvae to bioorganic films: Effects of large-scale variation in films. Journal of Experimental Marine Biology and Ecology, 207:59-78.

KERNEIS A (1960). Contribution à l'étude faunistique et écologique des herbiers de posidonies de la région de Banyuls. Vie Milieu, 11:161-187.

KeVERn NR, WiLhM JL \& VAN DYNe GM (1966). Use of artificial substrata to estimate the productivity of periphyton. Limnology \& Oceanography, 11:499-502.

LAVERY PS, ReID T, HyNDES GA \& VAN ElVEN BR (2007). Effect of leaf movement on epiphytic algal biomass of seagrass leaves. Marine Ecology Progress Series, 338:97-106.

LEE SY, FONG CW \& WU RSS (2001). The effects of seagrass (Zostera japonica) canopy structure on associated fauna: a study using artificial seagrass units and sampling of natural beds. Journal of Experimental Marine Biology and Ecology, 259:23-50

LEPOINT G, BALANCIER B \& GOBERT S (2014). Seasonal and depth-related biodiversity of leaf epiphytic Cheilostome Bryozoa in a Mediterranean 
Posidonia oceanica meadow. Cahiers de Biologie Marine, 55:57-67.

Lepoint G, NysSen F, Gobert S, Dauby P \& BOUQUEGNEAU JM (2000). Relative impact of a seagrass bed and its adjacent epilithic algal community in consumer diets. Marine Biology, 136:513-518.

LEPOINT G, JACQUEMART J, BOUQUEGNEAU JM, Demoulin V \& Gobert S (2007). Field measurements of inorganic nitrogen uptake by epiflora components of the seagrass Posidonia oceanica (Monocotyledons, Posidoniaceae). Journal of Phycology, 43:208-218.

MaBrouk L, HAMZA A, BEN BRAHIM M \& BRADAI MN (2011). Temporal and depth distribution of microepiphytes on Posidonia oceanica (L.) Delile leaves in a meadow off Tunisia. Marine Ecology, 32:148-161.

MagGi E, Bertocci I, VAselli S \& BenedettiCECCHI L (2011). Connell and Slatyer's models of succession in the biodiversity era. Ecology, 92:1399-1406.

Matricardi G, Montagna P \& Pisano E (1991). Settlement and growth strategies of Electra posidoniae Gautier on Posidonia oceanica (L.) Delile. Bulletin de la Société des Sciences Naturelles de l'Ouest de la France, HS1:255-262.

Mazzella L, SCIPIONE MB \& BUiA MC (1989). Spatio-temporal distribution of algal and animal communities in a Posidonia oceanica meadow. Marine Ecology, 10:107-129.

Mazzella L, Cinelli F, OtT JA \& Klepal W (1981). Studi sperimentali “in situ” sull'epifitismo della Posidonia oceanica Delile. Quaderni del Laboratorio di Tecnologia della Pesca, 3:481-492.

Mazzella L, Buia MC, Gambi MC, LoRenti M, Russo GF, SCIPIONE MB \& ZUPO V (1992). Plantanimal trophic relationships in the Posidonia oceanica ecosystem of the Mediterranean Sea: a review. In: JOHN DM, HAWKINS SJ \& PRICE JH (eds), Plant-animal Interactions in the Marine Benthos, Systematics Association Special Volume, Clarendon Press, Oxford:165-187.

MiCHEL L (2011). Multidisciplinary study of trophic diversity and functional role of amphipod crustaceans associated to Posidonia oceanica meadows. PhD Thesis, University of Liège.

MORRI C (1991). Présentation d'un indice synthétique pour l'évaluation de l'épiphytisme foliaire chez Posidonia oceanica (L.) Delile. Posidonia Newsletter, 4:33-37.
NOVAK R (1984). A study in ultra-ecology: microorganisms on the seagrass Posidonia oceanica (L.) Delile. Marine Ecology, 5:143-190.

Pergent-Martini C, Leoni V, Pasqualini V, Ardizzone GD, BALESTRI E, Bedini R, BellusCIO A, BELSHER T, BORg J, BOUdOURESQUe CF, BOUMAZA S, BOUQUeGNEAU JM, BuiA MC, Calvo S, Cebrian J, Charbonnel E, Cinelli F, Cossu A, Di Maida G, Dural B, Francour P, Gobert S, LEPOINT G, MEINESZ A, MOlenaAR H, Mansour hM, Panayotidis P, Peirano A, Pergent G, Piazzi L, Pirrotta M, Relini G, Romero J, SAnchez-Lizaso JL, Semroud R, SHEMBri P, TOMASELLOA\& Velimirov B (2005). Descriptors of Posidonia oceanica meadows: Use and application. Ecological Indicators, 5:213-230.

Soullard M, Bourge I, Fogel J, Lardinois D, MATHIEU T, VEESChKENS C, BAY D, DAUBy P \& BOUQUEGNEAU JM (1994). Evolution of the shoot density of the Posidonia oceanica seagrass bed of Calvi Bay (Corsica). Vie Milieu, 44:199-201.

THELIN I \& BoudOURESQue CF (1983). Longévité des feuilles de Posidonia oceanica dans un herbier superficiel de la Baie de Port-Cros (Var, France). Rapport de la Commission Internationale pour l'Exploration Scientifique de la Mer Méditerranée, 28:115-116.

TrautMan DA \& BorowitzKa MA (1999). Distribution of the epiphytic organisms on Posidonia australis and P. sinuosa, two seagrasses with differing leaf morphology Marine Ecology Progress Series, 179:215-229.

VAN DER BEn D (1971). Les épiphytes des feuilles de Posidonia oceanica Delile sur les côtes françaises de la Méditerranée. Institut Royal des Sciences Naturelles de Belgique, Mémoires, 168:101.

VAn Montfrans J, Wetzel RL \& ORTH RJ (1984). Epiphyte-grazer relationships in seagrass meadows: consequences for seagrass growth and production. Estuaries, 7:289-309.

Zieman JC \& Wetzel RL (1980). Productivity is seagrasses: Methods and rates. In: PHILLIPS RC \& MCROY CP (eds), Handbook of seagrass biology - An ecosystem perspective, Garland Publishing, New York:87-116.

Received: September 11th, 2014

Accepted: February 12th, 2015

Branch editor: Steven Degraer 